\title{
PENDIDIKAN KARAKTER BERBASIS KELUARGA
}

Oleh: Theodorus Uheng Koban Uer

\begin{abstract}
Abstrak:
\end{abstract}
$\mathrm{D}$ alam Dokumen Gaudium et Spes dinyatakan: "Keluarga merupakan suatu sekolah untuk memperkaya kemanusiaan. Supaya mampu memiliki kepenuhan hidup dan melaksanakan misinya, diperlukan komunikasi hati penuh kebaikan, kesepakatan suami-istri, dan kerja sama yang tekun dalam pendidikan anak". Dan sebagai Gereja Domestik atau Gereja Rumah Tangga, bapak ibu dan anak-anak diharapkan mampu membangun keluarganya dengan bantuan kasih Karunia Allah. Akan tetapi ada masalah yang muncul yakni apakah keluarga mampu melaksanakan pendidikan karakter yang bermakna bagi dirinya dan masyarakat sekitarnya dalam kondisi-kondisi moril, sosial, dan ekonomi yang serba tidak menguntungkan sekarang ini. Bagaimana perhatian penuh kasih dari Pemimpin Gereja Lokal dan Gereja Universal terhadap kondisi-kondisi ini? Tujuan penulisan ini untuk mendeskripsikan upaya-upaya Gereja Lokal dan Universal mempersiapkan keluarga-keluarga Kristen menghadapi tantangan tersebut. Metode yang dilakukan adalah membaca berbagai pustaka, mencatat berbagai pernyataan dari dokumen- dokumen Konsili Vatikan II, Pustaka Teologi terutama Teologi Keluarga. Hasil yang diharapkan ialah semoga tulisan ini dapat merangsang, mendorong, dan memotivasi para fungsionaris pastoral agar mampu mengemban tugas yang dipercayakan khususnya Komisi Pastoral Keluarga baik di tingkat Paroki maupun di tingkat keuskupan supaya meningkatkan perhatiannya terhadap pendidikan karakter dalam keluarga. Kiranya keluarga-keluarga semakin berkualitas dalam iman, harap, dan kasih serta ber-rekonsiliasi antarsesama dan terhadap Allah sebagai Pencipta Nafas Kehidupan untuk semuanya.

Kata kunci : pendidikan karakter, keluarga domestik, dokumen Konsili Vatikan II.

\section{Pendahuluan}

Pendidikan karakter sudah diluncurkan sebagai gerakan nasional pada tahun 2010. Hal ini selaras dengan gagasan Presiden RI, Joko Widodo, yang ingin melakukan Gerakan Nasional Revolusi Mental (GNRM). Gerakan ini akan diterapkan di seluruh sendi kehidupan berbangsa dan bernegara. Namun gerakan ini ternyata belum merata di seluruh Nusantara. Wilayah yang luas, dengan keragaman budaya, bahasa, ras, etnis, dan sebagainya menjadi kendala penghambat meratanya gerakan ini sebagai suatu revolusi mental.

Gerakan Nasional Revolusi Mental yang telah dimulai sejak tahun 2010 sudah dilaksanakan di sekolahsekolah dan didukung oleh Pemerintah Daerah dan masyarakat. Namun keluarga sebagai salah satu sendi untuk mengaplikasikan gerakan ini belum dilibatkan secara penuh untuk mendukung gerakan tersebut. Gerakan baru terkonsentrasi di sekolah-sekolah karena Pemerintah baik Pemerintah Pusat maupun Pemerintah Daerah beranggapan bahwa sekolah harus menjadi pusat pembentukan karakter sebab sekolah adalah tempat yang paling tampan untuk melaksanakan gerakan tersebut. Bahkan pada tahun 2015 mulai diadakan pelatihan Penguatan Pendidikan Karakter bagi guru-guru untuk memperkuat bakat, potensi, dan talenta seluruh peserta didik.

Sesungguhnya ada tiga sendi kehidupan berbangsa dan bernegara yang menjadi landasan pendidikan karakter yakni keluarga, sekolah, dan masyarakat. Dan yang menjadi fokus tulisan ini adalah keluarga. Keluarga 
adalah sel utama dan sangat vital kedudukannya serta fungsinya dalam masyarakat untuk terbentuknya pendidikan karakter atau wadah serta tumpuan bagi pendidikan karakter.

Dalam Sinode para Uskup yang diadakan di Roma tanggal 25 September sampai 25 Oktober 1980, para Uskup mengajukan berbagai proposal kepada Paus Yohanes Palus II tentang peran dan fungsi keluarga dalam kehidupan yang perlu dirawat dan dijaga serta dilindungi dari berbagai bahaya yang mengancam dari segala sisi kehidupan. Dan atas dasar proposal-proposal tersebut Paus Yohanes Paulus II mengeluarkan Anjuran Apostoliknya "Familiaris Consortio, Peranan Keluarga Kristiani dalam Dunia Modern", pada 22 November 1981. Paus mengawali tulisan, "Gereja diterangi oleh iman yang memberinya pengertian tentang segala kebenaran tentang tingginya nilai pernikahan dan keluarga, dan mengenai maknanya yang terdalam. Sekali lagi, Gereja merasakan betapa mendesaknya kebutuhan untuk mewartakan Injil, yakni Kabar Gembira kepada sekalian orang tanpa kecuali, khususnya kepada mereka semua yang meneima panggilan hidup berkeluarga, dan menyiapkan diri untuknya, kepada semua suami-istri serta orang tua di dunia semesta". Paus menyadari bahwa kesejahteraan masyarakat dan kebaikan sendiri erat sekali terikat pada kesejahteraan keluarga (Eminyan, 2001: 9-10).

Selanjutnya para Uskup Indonesia dalam Konferensi Wali Gereja Indonesia (KWI) membentuk Komisi Pastoral Keluarga baik di tingkat Nasional maupun di tingkat Keuskupan sampai dengan tingkat paroki untuk mendampingi keluarga-keluarga mulai dari pranikah sampai dengan pascanikah. Pendampingan atau pembinaan dilakukan secara berkesinambungan dengan program yang terencana, pelaksanaan yang teratur dan mengevaluasi secara tetap kegiatan tersebut agar kualitas kehidupan berkeluarga semakin hari semakin bermutu. Sementara itu para politisi dan pemerintahan negara RI sungguh menyadari bahwa keluarga memiliki ciri khas yang unik sehingga terdorong untuk menyusun UU perkawinan. Kekhasan kehidupan keluarga seharihari merupakan sumbangan yang mendasar dan utama untuk masyarakat, saling menghormati martabat masingmasing, penerimaan, pelayanan, dan solidaritas karena keluarga menjadi sekolah utama untuk kehidupan sosial kemasyarakatan.

Sedemikian pentingnya peran dan fungsi keluarga dalam masyarakat, maka PBB menetapkan Tahun 1994 menjadi Tahun Keluarga Internasional. Para pemimpin dunia melihat kehidupan keluarga digerogoti dengan berbagai kemajuan teknologi, pengaruh materialisme dan budaya hedonisme merusak seluruh tatanan kehidupan keluarga sehingga perlu dilakukan gerakan yang sejalan dengan keprihatinan Gereja sejagat terhadap kehidupan keluarga yang mernjadi inti sel kehidupan masyarakat, bangsa dan negara. Munculnya radikalisme, terorisme di mana-mana merupakan akibat dari rusaknya sel-sel kehidupan keluarga seperti perpisahan atau perceraian suami-istri, perselingkuhan, seks bebas, kemelaratan dan kemiskinan, perantauan, dan sebagainya. Gejala-gejala ini menyebabkan kerapuhan hidup berbangsa dan bernegara di Indonesia.

Dengan demikian keluarga yang menjadi sel-sel hidup dalam masyarakat membutuhkan penguatan pendidikan karakter untuk mewujudkan masyarakat Indonesia yang bermartabat, berbudaya Pancasila, berkarakter Bhineka Tunggal Ika. Untuk itu perlu difungsikan secara efektif peran para pemimpin masyarakat termasuk organisasi-organisasi kemasyarakatan dan lembaga-lembaga sosial serta organisasi-organisasi Gerejawi agar secara tetap mendampingi kehidupan keluarga.

\section{Pendidikan Karakter Sebagai Bagian dari Revolusi Mental}

Pada awal masa perjuangan pra-kemerdekaan sampai dengan awal proklamasi kemerdekaan Republik Indonesia, bangsa dan negara ini benar-benar kompak untuk mencapai cita-cita kemerdekaan dalam suatu negara proklamasi. Para pemuda yang berbeda etnik, budaya, dan bahasa, menjadi satu tanah, satu bangsa dengan satu bahasa persatuan yakni bahasa Indonesia. Hal ini terungkap dalam pernyataan yang disebut Sumpah Pemuda 28 Oktober 1928. Segenap masyarakat dan keluarga bangsa ini masing-masing bersedia 
mengembangkan identitasnya dan terbuka pada saudara-saudari yang berbeda, namun senasib dan sepenanggungan.

Konsensus kesediaan untuk saling menerima dalam identitas masing-masing terungkap seresmi-resminya dalam satu ideologi negara Pancasila. Pancasila mengungkapkan bahwa Indonesia adalah milik kita semua tanpa membedakan antara mayoritas dan minoritas, antara agama, etnik, ras, antargolongan dan budaya.

Dunia terus berubah termasuk Indonesia. Bangsa Indonesia menunjukkan dirinya bukan lagi sebagai masyarakat tradisional melainkan masyarakat modern yang individualistik. Frans Magnis Suseno, dalam bukunya Etika Politik: Prinsip Moral Dasar Kenegaraan Modern (2016) menyatakan ada empat gejala yang menunjukkan hal tersebut. Pertama, Indonesia memiliki sistem pendidikan modern yang sangat individualistik. Sistem penilaian berfokus pada prestasi individu. Kedua, hidup seseorang sangat ditentukan oleh kepemilikan uang secara individual. Bukan ekonomi pasar, melainkan ekonomi uang yang menentukan roda perputaran ekonomi. Ketiga, kita hanya mengenal administrasi kependudukan yang bersifat individualistik dan tidak mengenal KTP kolektif. Keempat, untuk mendapat pekerjaan orang harus menunjukkan prestasi individual. Penerapan sistem kekeluargaan dalam penempatan seseorang di lembaga swasta atau pemerintahan disebut KKN (Kolusi, Korupsi, dan Nepotisme) (Madung, 2017: 1-2).

Keempat gejala tersebut di atas sangat mempengaruhi pertumbuhan dan pengembangan mental serta karakter bangsa Indonesia mulai dari keluarga sampai ke masyarakat luas dan semakin menjamur dari hari ke hari. Untuk itu dibutuhkan suatu gerakan nasional yang secara cepat, tepat, dan efektif menanggulanginya agar tidak semakin merosotnya mental bangsa ini. Pada tahun 2010 Presiden Joko Widodo mencanangkan Gerakan Revolusi Nasional Mental (GNRM) yang kemudian ditindaklanjuti oleh Kementerian Pendidikan dan Kebudayaan RI untuk mengutamakan dan membudayakan pendidikan katarakter di dalam dunia pendidikan. Menurut Menteri Pendidikan dan Kebudayaan, Satuan pendidikan menjadi sarana strategis bagi pembentukan karakter bangsa karena memiliki sistem, infrastruktur, dan dukungan ekosistem pendidikan yang tersebar di seluruh Indonesia mulai dari perkotaan sampai ke pedesaan. Untuk itu diperlukan langkah-langkah yang lebih konkrit agar pemberdayaan nilai-nilai utama pembentukan karakter bangsa dapat dilakukan secara efektif dan menyeluruh.

Agar Gerakan Nasional Revolusi Mental berjalan selaras dan sesuai arahan Presiden, maka dibentuklah Tim yang menyusun dan menerbitkan buku-buku serta Modul Penguatan Pendidikan Karakter (PPK) yang terdiri dari Konsep dan Pedoman PPK, Panduan Penilaian PPK, Modul Pelatihan bagi Guru, Kepala Sekolah, Pengawas dan Komite Sekolah, serta Pedoman Pelaksanaan Pelatihan Calon Pelatih PPK.

Berdasarkan sumber atau referensi tersebut di atas penulis mengutip kelima nilai utama karakter bangsa yang menjadi prioritas Gerakan PPK (Penguatan Pendidikan Karakter) yang secara bertahap dimulai tahun 2015/2016. Dan agar masyarakat luas termasuk keluarga dapat memberikan masukan bagi pelaksanaan dan penyempurnaan kebijakan PPK ini maka para orang tua /wali yang dibantu oleh Komite Sekolah perlu memahami dan mengimplementasikan kelima nilai utama tersebut dalam kehidupan keluarga. Sebab sesungguhnya kehidupan keluarga menjadi basis untuk penerapan kelima nilai utama tersebut dalam keseharian hidupnya. Selanjutnya kelima nilai utama karakter bangsa yang menjadi prioritas Gerakan PPK dibahas dan diuraikan sebagai berikut.

Pertama, Nilai Karakter Religius. Nilai ini mencerminkan keberimanan terhadap Tuhan yang Maha Esa yang diwujudkan dalam perilaku melaksanakan ajaran agama dan kepercayaan yang dianut, menghargai perbedaan agama, menjunjung tinggi sikap toleran terhadap pelaksanaan ibadah agama dan kepercayaan lain, hidup rukun dan damai dengan pemeluk agama lain. Dan yang menjadi subnilai Karakter Religius adalah cinta 
damai, toleransi, menghargai perbedaan agama dan kepercayaan, anti-bullying dan kekerasan, persahabatan, ketulusan, tidak memaksakan kehendak, mencintai lingkungan, melindungi yang kecil dan tersisih.

Kedua, Nilai Karakter Nasionalis. Nilai ini merupakan cara berpikir, bersikap, dan berbuat yang mewujudkan kesetiaan, kepedulian, dan penghargaan yang tinggi terhadap bahasa, lingkungan fisik, sosial, budaya, ekonomi, dan politik bangsa, menempatkan kepentingan bangsa dan negara di atas kepentingan diri dan kelompoknya. Dan yang menjadi sub-nilai Karakter Nasionalis adalah apresiasi budaya bangsa sendiri, menjaga kekayaan budaya bangsa, rela berkorban, unggul dan berprestasi, cinta tanah air, menjaga lingkungan, taat hukum, disiplin, menghormati keragaman budaya, suku, dan agama.

Ketiga, Nilai Karakter Mandiri. Nilai ini merupakan sikap dan perilaku tidak bergantung pada orang lain, dan mempergunakan segala tenaga, pikiran, waktu untuk merealisasikan harapan, mimpi dan cita-cita. Dan yang menjadi subnilai Karakter Mandiri adalah etos kerja (kerja keras) tangguh, tahan banting, daya juang, profesional, kreatif, keberanian dan menjadi pembelajar sepanjang hayat.

Keempat, Nilai Karakter Gotong Royong. Nilai ini mencerminkan tindakan menghargai semangat kerja sama dan bahu membahu menyelesaikan persoalan bersama, menjalin komunikasi dan persabatan, memberi bantuan/pertolongan pada orang-orang yang membutuhkan. Dan yang menjadi subnilai Karakter Gotong Royong adalah menghargai, kerja sama, inklusif, komitmen atas keputusan bersama, musyawarah mufakat, tolong menolong, solidaritas, empati, antidiskriminasi, antikekerasan, dan hidup kerelawanan.

Kelima Nilai Karakter Integritas. Nilai ini mendasari perilaku yang didasarkan pada upaya menjadikan dirinya sebagai orang yang selalu dapat dipercaya dalam perkataan, tindakan, dan pekerjaan, memiliki komitmen dan kesetiaan pada nilai-nilai kemanusiaan dan moral (integritas moral). Karakter integritas meliputi sikap tanggung jawab sebagai warga negara, aktif terlibat dalam kehidupan sosial melalui konsistensi tindakan dan perkataan yang berdasarkan kebenaran. Dan yang menjadi subnilai Karakter Integritas adalah kejujuran, cinta pada kebenaran, setia, komitmen moral, antikorupsi, keadilan, tanggung jawab, keteladanan, dan menghargai martabat individu (terutama penyandang disabilitas).

Demikianlah paparan kelima nilai utama karakter bangsa yang menjadi prioritas Gerakan PPK yang diharapkan dapat diimplementasikan secara integral dalam kehidupan berkeluarga.

\section{Kehidupan Keluarga Sebagai Basis Pendidikan Karakter}

Keluarga adalah suatu komunitas cinta kasih, hidup, dan keselamatan. Definisi ini berlaku secara keseluruhan, khsususnya keluarga Kristiani. Setiap keluarga hendaknya menjadi keluarga menurut rencana Allah. Akan tetapi dosa telah merusak rencana Allah terhadap umat manusia. Meskipun demikian rencana ini telah dipulihkan kembali melalui Inkarnasi, Wafat, dan Kebangkitan Tuhan Yesus Kristus. Akan tetapi kerapuhan hati nurani manusia menjadi penyebab rencana Allah tersebut perlu terus menerus diperbaharui. Dengan demikian dosa-dosa yang membanjiri kehidupan masyarakat menyebabkan hidup perkawinan gagal, tidak sempurna, bahkan membuat kehidupan keluarga menjadi pecah dan hancur berantakan (bdk. Eminyan, 2001: 20).

\subsection{Keluarga sebagai Komunitas Cinta Kasih}

Kehidupan keluarga sebagai komunitas cinta kasih akan memancarkan nilai-nilai karakter religius karena keluarga akan mencerminkan keberimanan terhadap Tuhan Yaang Maha Esa yang diwujudkan dalam cinta akan sesama. "Aku memberi perintah baru bagi kamu, yaitu supaya kamu saling mengasihi; sama seperti Aku telah mengasihi kamu, demikian pula kamu harus saling mengasihi”(Yoh,13: 34). Dengan keyakinan ini akan muncul 
cinta damai, saling menghargai, saling melibatkan, karena saling membutuhkan. Dengan demikian apabila terjadi kemalangan dalam keluarga, setiap anggota keluarga akan saling melindungi terutama terhadap anggota keluarga yang lemah dan sakit atau menderita.

Komunitas keluarga akan memancarkan pula nilai integritas yang akan diwujudnyatakan dalam karakter kejujuran, setia satu sama lain, komitmen moral, menghargai martabat individu terutama penyandang disabilitas. Pasangan suami-istri, keduanya telah memutuskan untuk hidup bersama atas dasar cinta kasih. Selanjutnya atas dasar cinta pula mereka melahirkan anak-anaknya, merawat, membesarkan, dan mendidik serta mendewasakan anak-anak tersebut.

Bapa dan ibu serta anak-anaknya mengemban cinta kasih dalam Ecclesia Domestica atau Gereja Rumah Tangga sesuai rencana Allah. "Allah adalah Kasih” (bdk. 1 Yoh, 4: 7-21). Karena kasih-Nya Allah menciptakan manusia menurut citra-Nya. "Baiklah Kita menjadikan manusia menurut Gambar dan Rupa Kita.” (Kej, 1: 26). Dan semua itu mulai dari alam semesta sampai manusia itu baik semuanya. Akan tetapi berbeda dengan ciptaan yang lain, manusia memiliki kemiripan dengan Allah sebagai cermin Allah atau citra Allah. Dengan demikian kekuasaan Allah untuk mencipta, membagi kebaikan, mengatur lingkungan, dan sebagainya, harus selaras dengan kehendak Allah. "Maka Allah menciptakan manusia itu menurut gambar-Nya, menurut gambar Allah diciptakan-Nya dia; laki-laki dan perempuan diciptakan-Nya mereka. Allah memberkati mereka, lalu Allah berfirman kepada mereka, "Beranakcuculah dan bertambah banyak; penuhilah bumi dan taklukkanlah itu, berkuasalah atas ikan-ikan di laut dan burung-burung di udara dan atas segala binatang yang merayap di bumi." Kej, 1:27-28).

Akan tetapi Kasih Allah yang diberikan Allah kepada manusia tersebut dihancurkan oleh manusia. Relasi Kasih Allah itu hancur berantakan oleh dosa manusia tersebut. Dosa melawan Kasih Allah membanjiri kehidupan manusia. Namun demikian karena Allah adalah Kasih maka Allah sendiri yang berinnisiatip memulihkan relasi Kasih-Nya itu dengan mengutus Putera-Nya Yang Tunggal Yesus Kristus untuk menebus manusia dari dosanya. Meskipun demikian karena kerapuhan hatinya, manusia terus-menerus jatuh ke dalam dosa pribadi dan kelompok.

Sementara itu manusia yang berkehendak baik ingin memulihkan hubungan Kasih dengan Allah dan sesama melalui berbagai upaya. Dan salah satu upaya adalah melalui pendidikan yang diemban oleh setiap anggota keluarga. Dan untuk itu perlu diperhatikan pendidikan karakter berbasis keluarga karena keluargalah menjadi wadah proses pendidikan yang utama. Bapa bersama ibu atau suami-istri menjadi pendidik utama dalam keluarganya.

\subsection{Keluarga sebagai Komunitas Hidup}

Sebagai komunitass hidup, pasangan suami-istri melakukan prokreasi penuh cinta sebagai partisipasi dalam karya penciptaan Allah. Prokreasi tidak hanya dibatasi pada menurunkan kehidupan baru melainkan menjadi kewajiban keduanya merawat, melindungi, menumbuhkembangkan dan membantu anak-anak yang dilahirkan mencapai kedewasaan karena Allah tak pernah berhenti mencipta kehidupan.

Konsili Vatikan II sangat menekankan pentingnya pendidikan dalam keluarga dan meletakkan prinsip-

prinsip mendasar. "Keluarga merupakan suatu sekolah untuk memperkaya kemanusiaan. Supaya keluarga mampu mencapai kepenuhan hidup dan misinya, diperlukan komunikasi penuh kebaikan. Kesepakatan suamiistri, dan kerja sama orang tua yang tekun dalam pendidikan anak-anaknya.... Melalui pendidikan hendaklah anak dibina sedemikian rupa, sehingga bila nanti mereka sudah dewasa, mereka mampu penuh tanggung jawab mengikuti panggilan mereka, juga panggilan religius, serta memilih status hidup mereka. Maksudnya juga, 
supaya bila kemudian mereka mengikat diri dalam pernikahan, mereka mampu membangun keluarga mereka sendiri dalam kondisi-kondisi moril, sosial, dan ekonomis yang menguntungkan Merupakan kewajiban orang tua atau para pengasuh, membimbing mereka yang lebih muda dalam membentuk keluarga dengan nasihat bijaksana, yang dapat mereka terima dengan senang hati" (Eminyan, 2001: 153-154).

Dalam Gravissimum Educationes ditekankan pula, "Karena orang tua telah menyalurkan kehidupan kepada anak-anaknya, terikat kewajiban amat berat untuk mendidik mereka, maka orang tualah yang harus diakui sebagai pendidik mereka yang pertama dan utama. Begitu pentinglah tugas mendidik itu, sehingga bila diabaikan, sangat sukar pula untuk dilengkapi. Sebab merupakan kewajiban orang tua menciptakan lingkup keluarga, yang diliputi semangat bakti kepada Allah dan kasih sayang terhadap sesama sedemikian rupa, sehingga menunjang kebutuhan pendidikan pribadi dan sosial anak-anak mereka”.

Dengan demikian, keluarga merupakan lingkungan pendidikan pertama keutamaan-keutamaan sosial yang dibutuhkan oleh setiap masyarakat. Adapun terutama dalam keluarga Kristen, yang diperkaya dengan rahmat dan kewajiban sakramen perkawinan, anak-anak sudah sejak dini harus diajar mengenal Allah serta berbakti kepada-Nya dan mengasihi sesama, seturut iman yang telah mereka terima dalam sakramen Baptis. Di situlah anak-anak menemukan pengalaman pertama akan masyarakat manusia yang sehat serta Gereja. Melalui keluargalah akhirnya mereka lambat laun diajak berintegrasi dalam masyarakat manusia dan umat Allah. Oleh karena itu, hendaklah para orang tua menyadari betapa pentingnya kehidupan keluarga yang sungguh kristiani untuk kehidupan dan kemajuan umat Allah sendiri.” (Eminyan 2001 : 154)

Bertumpu pada uraian di atas, maka perlulah diperhatikan dengan sungguh-sungguh pendidikan karakter dalam keluarga dalam mengimplementasikan nilai-nilai karakter yang selaras dengan Gerakan Nasional Revolusi Mental. Nilai karakter religius sebagaimana yang telah dikemukakan di atas perlu dikondisikan dalam kehidupan keluarga. Misalnya, mengajar anak-anak berdoa, melakukan doa bersama, mengikuti perayaan Ekaristi dengan sungguh-sungguh, dan sebagainya. Dan di samping itu nilai karakter mandiri, gotong royong, serta nilai integritas perlu ditumbuhkembangkan secara baik dan tepat. Misalnya mengamalkan etos kerja, mengembangkan kreativitas anak, menghargai kejujuran, setia dan hormat terhadap pasangan hidup sehingga menjadi panutan bagi anak-anaknya.

Perilaku-perilaku yang baik dalam kehidupan berkeluarga akan mempengaruhi masyarakat sekitar terutama para tetangga, anggota Komunitas Umat Basis (KUB), dan sebagainya. Kebiasaan-kebiasaan tersebut akan dibawa anak-anak ke sekolah dan akan diperkuat oleh sekolah melalui latihan-latihan untuk memperoleh keterampilan hidup bermasyarakat.

\subsection{Keluarga sebagai Komunitas Keselamatan}

Dalam Gaudium et Spes No 48 dinyatakan "Sebab seperti dulu Allah menghampiri bangsa-Nya dengan perjanjian dan kesetiaan, begitu pula sekarang Penyelamat Umat manusia dan Mempelai Gereja melalui sakramen perkawinan menyambut suami-istri kristiani .... Kasih sejati suami-istri ditampung dalam cinta Ilahi, dan dibimbing serta diperkaya berkat daya penebusan Kristus serta kegiatan Gereja yang menyelamatkan”. Tampak dalam deklarasi Konsili Vatikan II itu, keluarga tidak hanya merupakan komunitas cinta kasih dan komunitas hidup, tetapi juga merupakan komunitas keselamatan. Melalui cara yang istimewa inilah pasangan suami-istri, yang percaya kepada Kristus Sang Penebus dimeteraikan oleh sakramen Baptis yang mempersatukan mereka dalam Tubuh Mistik Kristus yakni Gereja. Jadi, dalam sakramen perkawinan, pemberian diri dalam cinta kasih secara timbal balik menjadi sumber rahmat serta menjadi sarana keselamatan bagi mereka. Keluarga yang dilahirkan dalam persatuan sebagai suami-istri dalam Gereja benar-benar 
merupakan Gerja Rumah Tangga dan secara analogi mempunyai sifat serta ciri yang sama dengan Gereja Universal (bdk. Eminyan, 2001: 173-176).

Ciri-ciri Gereja adalah satu, kudus, katolik, dan apostolik. Satu berarti setiap anggota keluarga memiliki iman yang sama pada Kristus yang sungguh menjadi mempelai Gereja. Kudus berarti setiap anggota keluarga saling menguduskan karena saling mencintai, menghormati, menghargai, dan melibatkan diri satu sama lain sebagaimana yang dilakukan Kristus terhadap Gereja-Nya. Katolik artinya umum. Namun yang dimaksud dengan katolik berarti sama dan setara serta tidak membeda-bedakan antar anggotanya. Bahkan setiap anggota keluarga harus melindungi anggota yang paling lemah dan tak berdaya. Setiap anggota keluarga harus sungguh menghayati nilai-nilai integritas dalam kehidupan keluarga. Apostolik artinya setiap anggota keluarga melaksanakan karya kerasulan bersama-sama karena keluarga sebagai sakramen, keluarga sebagai Gereja domestik, dan keluarga sebagai penginjil.

Berdasarkan pembahasan di atas, dapatlah disimpulkan bahwa keluarga sungguh menjadi wadah utama bagi pendidikan karakter. Kelima nilai utama karakter bangsa yakni nilai religius, nilai karakter nasionalis, nilai karakter mandiri, nilai karakter gotong royong, dan nilai karakter integritas dengan berbagai subnilainya perlu disosialisasikan kepada setiap keluarga sebagai warga bangsa dan negara ini. Di samping memahami, setiap warga bangsa terutama keluarga Kristiani perlu menghayati dan mengamalkannya dalam keseharian hidup mereka.

\section{Peran Dan Fungsi Pastoral Keluarga Sebagai Pendamping Dan Pembina Kehidupan Keluarga Kristiani}

Peran dan fungsi pastoral keluarga akan tampak secara hirarkis mulai dari Gereja Universal, Gereja Nasional, Gereja Keuskupan, dan Gereja Parokial. Bentuk eklesial Gereja Universal yakni umat Allah yang meliputi semua orang yang dibaptis serta hidup di dalam Gereja Katolik. Bentuk yang kedua adalah Gereja Nasional yakni seluruh persekutuan orang kristen di dalam suatu negara atau bangsa tertentu. Di dalam Gereja Nasional perlu diakui pentingnya kekhasan-kekhasan budaya dan daerah yang menyumbang kekayaan Gereja Universal. Sejak Konsili Vatikan II sumbangan Konferensi para Uskup menjadi sangat berharga, tidak hanya bagi negara atau daerah-daerah yang diwakili tetapi juga bagi Gereja dalam skala yang lebih luas. Bentuk ketiga dari kehidupan Gerejawi adalah bentuk Keuskupan. Konsili Vatikan II menekankan peranannya sebagai kepenuhan kuasa Kristus yang terwujud melalui pribadi Uskup Lokal. Peran seorang Uskup mewujudkan pelayanannya meneruskan kehadiran Kristus di antara sesama. Bentuk keempat yang dipilih Konsili Vatikan II adalah komunitas lokal dengan pastor Paroki sebagai kepalanya. Dan bentuk kelima dari komunitas autentik adalah Gereja Domestik atau Gereja Rumah Tangga. Inilah Gereja yang membangun fondasi iman, kasih, harapan, dan pengampunan. Setiap keluarga perlu menyadari dan menghargai panggilannya yang penting sebagai sel terkecil (nucleus) dari Gereja Universal.

Berdasarkan pembahasan ini maka tampaklah seluruh gerak pelayanan Gereja bagi keluarga yang berawal dari Gereja Universal sampai ke Gereja Parokial. Misalnya, untuk melayani kebutuhan keluarga, seperti pembinaan dan pendampingannya dibentuklah Pastoral Keluarga mulai dari Gereja Universal sampai dengan Gereja Parokial.

Para Paus sebagai pemimpin Gereja Universal memiliki komitmen yang kuat terhadap kehidupan keluarga. Konsili Vatikan II dalam Gaudium et Spes menetapkan suatu traktat yang berjudul Martabat Perkawinan dan Keluarga yang memperlihatkan bahwa keselamatan pribadi maupun masyarakat manusiawi dan kristiani erat hubungannya dengan kerukunan hidup perkawinan dan keluarga. Paus Paulus VI dalam Ensekliknya Humanae Vitae dan Yohanes Paulus I, meskipun hanya sebulan menduduki takhta Petrus, 
menekankan hal yang sama. Kemudian Paus Yohanes Paulus II menyatakannya dalam Familiaris Consortio dan surat beliau kepada keluarga-keluarga yang dikeluarkannya pada Pesta Keluarga Kudus pada tahun 1993 sebagai persiapan awal menuju tahun Yubileum Agung tahun 2000. Demikian pula pesan beliau pada tahun 1994 dalam sidang umum PBB. Kemudian PBB menetapkan tahun tersebut sebagai Tahun Keluarga Sejagat. "Keluarga sebagai komunitas pendidikan yang utama dan mendasar, merupakan sarana istimewa bagi penerusan nilai-nilai agama dan budaya yang membantu seseorang memperoleh identitas sendiri. Didirikan atas dasar cinta dan terbuka terhadap anugerah kehidupan, keluarga mengandung di dalam dirinya sendiri masa depan masyarakat juga; tugas yang sangat khas adalah memberikan sokongan secara efektif bagi suatu masa depan perdamaian”. Demikian pesan Paus Yohanes Paulus II dalam Sidang Umum tersebut. Masih banyak pesan lagi sesudahnya bagi keluarga-keluarga yang beraudiensi dengan beliau. Pesan-pesan tersebut djabarkan lebih lanjut oleh Komisi Pastoral KWI, Keuskupan, dan dilanjutkan ke Paroki-Paroki.

\subsection{Persiapan Hidup Perkawinan dan Keluarga}

Dalam berbagai pesannya, Paus Yohanes Paulus II menganjurkan persiapan hidup perkawinan dan keluarga dibagi menjadi tiga tahap persiapan yakni persiapan jauh, dekat, dan langsung. Pertama, persiapan jangka jauh dimulai pada awal-awal tahun kehidupan seorang anak sampai kepada masa remaja. Hal ini dapat dilihat pada keluarga-keluarga yang berpendidikan. Ada sebagian keluarga yang anaknya ketika masih bayi dibaringkan bersama mamanya karena masih menyusui. Akan tetapi ketika mulai memasuki masa kanak-kanak atau masuk sekolah dasar anak-anak perempuan mempunyai kamar sendiri dan anak-anak laki-laki di kamarnya sendiri pula. Namun sebagian besar keluarga terutama di pedesaan, semua anak baik laki-laki maupun perempuan tidur bersama di sebuah kamar yang besar. Padahal dengan adanya pemisahan ini tercipta suatu kondisi psikologis yang positif. Dan secara tidak sadar akan berkembang nilai karakter saling menghargai, mengakui, dan menghormati sebagai lawan jenis. Maing-masing mereka mengetahui dan menghargai satu sama lainnya.

Kedua, Persiapan jangka dekat, yang dimulai kurang lebih pada masa remaja. Pada saat ini baik anak lakilaki maupun anak perempuan mulai bertanya tentang arti hidup dan berpikir tentang masa depan mereka. Kebanyakan orang tua sering mengabaikan kebutuhan anak-anak remaja terutama rangsangan seksual bagi anak remaja. Demikian pula kehidupan keagamaan para remaja sering tidak diacuhkan oleh orang tua. Mereka lebih memperhatikan tugas dan kewajiban remaja sebagai seorang wanita atau seorang laki-laki. Gagasan-gagasan yang disajikan dalam media sosial sangat diperhatikan remaja, terutama gagasan yang bersifat negatif dan provokatif. Akhirnya ada yang takut kawin tetapi memutuskan hidup bersama tanpa ikatan perkawinan yang sah, baik sipil atau agama. Dan untuk mengurangi hal-hal yang negatif orang tua perlu dibantu oleh serikatserikat remaja seperti OMK (Orang Muda Katolik), SEKAMI (Serikat Kerasulan Anak-anak Misioner), dan sebagainya. Kerja sama lintas komisi atau seksi perlu mendapat perhatian para Pastor Paroki.

Ketiga, Persiapan langsung bagi perayaan Sakramen Perkawinan. Persiapan ini dilakukan bagi pasangan yang bertunangan atau secara serius telah memilih pasangan hidupnya. Persiapan ini diawali dengan "Kursus Persiapan Perkawinan”. Gereja Lokal telah dan sedang dengan sungguh-sungguh melaksanakan kegiatan ini. Pimpinan Gereja bersama keluarga telah bekerja sama melaksanakan kegiatan ini. Oleh sebab itu setiap pasangan wajib mengikuti "Kursus Persiapan Perkawinan" tersebut. Materi penyajiannya bervariasi dalam setiap Paroki dan Keuskupan. Namun yang menjadi topik utama adalah Makna Sakramen Perkawinan atau Perkawinan sebagai Sakramen, Moral Pekawinan, Relasi Komunikasi dalam Hidup Perkawinan dan Keluarga, Seksualitas dalam Hidup Perkawinan, Ekonomi keluarga, Pendidikan Anak, Hidup Doa dan Kitab Suci sebagai Penyanggah Hidup Keluarga, Pemahaman Adat dan Budaya, dan sebagainya. 


\subsection{Pendampingan Hidup Perkawinan Pascanikah}

Perkawinan sebagai sakramen yang permanen bagi pasangan suami-istri. Berbeda dengan penerimaan sakramen lainnya, dalam upacara Liturgi Ekaristi, setiap pasangan saling memberikan diri sebagai sakramen satu dengan yang lainnya. Kristus hadir dalam diri setiap pasangan. Suami menjadi sakramen bagi istrinya dan istri menjadi sakramen bagi suaminya. Kasih Kristus adalah dasar hidup suami-istri (bdk. Ef, 5: 27-33). Pasangan suami-istri serta anak-anak yang dilahirkan telah membentuk sebuah komunitas keselamatan karena Kristus Sang Penyelamat hadir di dalam keluarga tersebut. Dan karunia Kasih Kristus harus tetap hadir dalam perjalanan hidup keluarga. Namun karena kerapuhan hati hidup manusia, mereka mengalami jatuh bangun dalam perjalanan hidup perkawinan dan keluarga. Oleh sebab itu setiap anggota komunitas keluarga perlu terusmenerus memohon kuasa Roh Kudus dengan Tujuh Karunia-Nya untuk hadir secara tetap dalam keluarga. Hal itu dilakukan lewat penerimaan Sakramen Ekaristi, Sakramen Tobat/Rekonsiliasi, dan Doa serta Devosi sakramental lainnya seperti doa Rosari, melakukan Ziarah, dan sebagainya. Jadi, selain penerimaan sakramen, keluarga membutuhkan bantuan-bantuan spiritual lainnya yang biasanya dikenal sebagai rahmat sakramental memang sangat diperlukan. Setiap anggota keluarga perlu saling menyelamatkan.

Ketika pasangan suami-istri merayakan pernikahannya, pada layar latar belakang selalu tampak dua lukisan. Ada sepasang burung merpati dan sebuah biduk yang sedang berlayar. Kedua burung merpati tersebut biasanya terbang menurut arah angin tetapi selalu kembali ke sangkarnya atau rumahnya. Rumah adalah home bagi setiap anggota keluarga, bukan house atau penginapan. Home adalah tempat setiap anggota keluarga menjalin kasih, hidup, dan keselamatan sebagai Kasih Karunia Allah bagi penghuninya. Dan biduk yang sedang berlayar melambangkan rumah tangga tempat bapa ibu dan anak-anak berjuang bersama mencari rezeki dan bapa-ibu menjadi nakhodanya. Dengan demikian setiap anggota komunitas menjadikan rumahnya sebagai home tempat setiap mereka "bergotong royong dalam kebersamaan sakramental". Melalui dialog yang terus-menerus dilakukan akan terjalin kasih, hidup, dan keselamatan bagi hidup perkawinan dan keluarga.

Kenyataan menunjukkan bahwa semua yang disebutkan di atas tidak mudah melaksanakannya. Sebab zaman terus berubah, khususnya bagi bangsa dan Negara ini. Bangsa ini memiliki keberagaman budaya, agama, ras dan golongan. Kelompok agama ada macam-macam. Ada penganut agama liberal dan ada pula yang literal. Ada kelompok yang memiliki toleransi tetapi ada pula yang intoleransi. Ada kelompok agama yang memaksakan kehendaknya. Perbedaan-perbedaan ini menimbulkan konflik horizontal Kemudian orang mempertanyakan "Kemanakah Negara yang Bhineka Tunggal Ika?” (bdk. Madung, 2017: 156).

Keadaan seperti ini sangat mengganggu ketentraman dan kenyamanan kehidupan berkeluarga. Dengan demikian komunitas ini membutuhkan pendampingan sebab selain gangguan ekstern seperti yang disebutkan masih ada banyak gangguan lain yang intern sifatnya. Perceraian, perselingkuhan, masalah ekonomi, perantauan, kemiskinan, penghasilan, dan sebagainya merupakan masalah yang sangat rentan dalam hidup berkeluarga.

Pendampingan pascanikah memang sulit dilaksanakan namun harus dibuat. Untuk itu Paskel perlu dibantu oleh organisasi Gerejawi seperti Marriage Encounter, Pasukris, Legio Maria, dan organisasi Gerejawi lainnya. Memang ada faktor ekstern dan intern seperti telah disebutkan di atas. Akan tetapi pendampingan pascanikah sangat perlu dan dibutuhkan. Akan tetapi kebanyakan pasangan suami-istri merasa hidup perkawinan mereka sudah baik dan biasa-biasa saja. Padahal setelah menikah mereka mulai melihat bahwa keduanya memiliki banyak perbedaan, antara lain, perbedaan psikologis seperti gaya kepribadian (personality style), perilaku yang berbeda, termasuk kebiasaan-kebiasaan, dan sebagainya. Perbedaan pandangan terhadap pendidikan anak, pengelolaan ekonomi keluarga karena pasangannya tak berpenghasilan tetap, dan lain-lain. 
Semua perbedaan teersebut sering memunculkan konflik yang berkepanjangan. Pertengkaran dan kekerasan fisik mengakibatkan pisah meja makan, pisah ranjang, dan lain-lain lalu terjadi perselingkuhan. Anak-anak menyaksikan semua ini sehingga pendidikan karakternya tidak berjalan segaimana mestinya. Pendidikan karakter di sekolah tidak banyak berpengaruh karena basisnya di keluarga rapuh dan berantakan. Oleh sebab itu perlu diprogramkan oleh Paskel untuk pendampingan para pasutri balita, pasutri madia, dan pasutri lansia.

Selama lebih dari 20 (dua puluh) tahun penulis terlibat dan melibatkan diri dalam kegiatan Paskel, baik di tingkat Keuskupan maupun paroki; yang agak berhasil adalah Kursus Persiapan Perkawinan tetapi Pendampingan Pasutri Pascanikah belum berhasil sepenuhnya. Pendampingan ini penting sebab yang melakukan persiapan jangka jauh dan persiapan jangka dekat sebagaimana Pesan Paus dilakukan oleh Pasutri Pascanikah. Terutama persiapan jangka dekat bagi para remaja belum dilaksanakan dengan baik oleh para Pasutri Pasca nikah bagi anak-anaknya khususnya pendidikan karakter.

\section{PENUTUP}

Dunia terus berubah, terutama dalam abad XXI ini. Salah satu tanda perubahan yang palng menonjol adalah berlangsungnya revolusi digital semakin luar biasa yang mengubah sendi-sendi kehidupan, kebudayaan, peradaban, dan kemasyarakatan termasuk pendidikan. Di Indonesia sama dengan banyak negara lain, konflikkonflik sosial yang paling mudah meledak berdasarkan kemajemukan etnis. Hidup bersama dengan etnik berbeda, apalagi kalau agama juga berbeda, dapat menimbulkan konflik. Perasaan eksklusif terhadap agama atau etnis sendiri dapat membuat seseorang selalu merasa curiga terhadap sesamanya yang beragama atau beretnis lain. Maraknya hoax (berita bohong) di media-media dapat membakar sentimen keagamaan.

Jalan pintas yang dianjurkan para relawan pemerhati pendidikan sumber daya manusia adalah membaca. Mereka membentuk kelompok "Pustaka Keliling" dengan ojek, membawa kantong-kantong atau tas-tas serta kopor-kopor yang berisi buku atau anyaman-anyaman kulit pohon (Irian Jaya). Mereka mengorbankan waktu dan tenaga untuk berkeliling dari daerah ke daerah mendatangi anak-anak untuk membaca buku. Karena mereka yakin bahwa membaca buku atau majalah-majalah memperluas wawasan pembacanya. Mereka berpendapat bahwa rendahnya minat baca membuat orang mudah terprovokasi hoax (berita bohong), keberpihakan tanpa filter hingga terjebak dalam fanatisme sempit. Perang melawan hoax, perang melawan radikalisme, perang melawan fanatisme sempit harus dimulai dengan membangun budaya membaca.

Sementara itu Pemerintah melakukan sebuah gerakan yang disebut Gerakan Nasional Revolusi Mental (GNRM). Gerakan ini mengedepankan lima nilai utama karakter bangsa yakni karakter religious, nilai karakter nasionalis, nilai karakter gotong royong, dan nilai karakter integritas. Nilai-nilai karakter tersebut perlu ditumbuhkembangkan mulai dari keluarga, sekolah dan masyarakat luas. Sejak tahun 2015 sudah dilakukan Gerakan Penguatan Pendidikan Karakter, terutama untuk sekolah-sekolah. Para Tim Penyusun Buku, Modul yang diperuntukan bagi guru-guru Sekolah Dasar, Menengah, dan Atas telah melakukan tugasnya dengan baik dan berhasil. Pelatihan-pelatihan pun telah dan sedang dilakukan. Namun sendi kehidupan masyarakat dan keluarga belum mendapat porsi yang memadai. Padahal keluarga merupakan basis pendidikan karakter bagi masyarakat luas.

Oleh sebab itu tulisan ini ingin merangsang, memotivasi para fungsionaris pastoral terutama Pastoral Keluarga baik di tingkat Keuskupan maupun Paroki agar secara terencana memprogramkan pendampingan para calon pasutri yang mengikuti kegiatan Kursus Perkawinan (pranikah) tetapi yang lebih penting adalah bagi pasutri pascanikah. 
Menurut para ahli Teologi bahwa keluarga modern dapat dikategorikan sebagai nucleus atau inti kehidupan masyarakat sedang mengalami banyak tantangan. Keluarga itu seperti atom, mudah terbelah dan disertai dengan penghancuran dan perubahan besar. Dan terpecahnya keluarga sekarang ini menjadi kenyataan. Akibatnya pendidikan dalam keluarga menjadi hancur berantakan. Dari data yang ter-rekam bahwa anggota kelompok radikalisme, ISIS, dan fanatisme sempit lainnya berasal dari keluarga-keluarga yang terpecah dan hancur berantakan. Dan untuk mewaspadai hal-hal tersebut, keluarga-keluarga kita sangat membutuhkan pendampingan. Barangkali Gereja Lokal kita masih merasa nyaman sehingga tak perlu cemas. Padahal berdasarkan beberapa data yang direkam oleh PBB, bangsa Indonesia adalah masyarakat religius namun sangat intoleran dalam bersikap terhadap kelompok agama-agama yang lain.

Mudah-mudahan gagasan-gagasan dalam tulisan ini dapat merangsang dan memotivasi para fungsionaris pastoral untuk melayani kebutuhan keluarga-keluarga Katolik dengan dan dalam Roh Kristus sendiri. Kiranya Gereja yang dibangun sejak kehidupan Umat Perdana terus bertumbuh dan berkembang berkat Ketujuh Karunia Roh Kudus, terutama Gereja Domestik dalam Paroki-Paroki.

\section{Kepustakaan}

\section{Dokumen-dokumen}

Konsili Vatikan II, 1965, Gaudium et Spes, Roma.

Konsili Vatikan II, 1965, Gaudium et Spes No: 3 Gravissimum Educationis, Pernyataan tentang Pendidikan Kristen.

Konsili Vatikan II, 1965, Gaudium et Spes No: 32 Pernyataan tentang Pentingnya Pendidikan dalam keluarga dan peletakan prinsip-prinsip mendasar.

Yohanes Paulus II, 2011, Anjuran Apostolik Familiaris Consortio, Dokpen KWI, Jakarta

Yohanes Paulus II, 2011, Surat kepada Keluarga-keluarga, Dokpen KWI, Jakarta

\section{Buku-Buku}

Eminyan, Maurice, 2001, Teologi Keluarga, diterjemahkan oleh Pustaka Teologi, Penerbit Kanisius, Yogyakarta

Madung, Otto Gusti, 2017, Post-Sekularisme, Toleransi dan Demokrasi, Penerbit Ledalero, Maumere, Percetakan Moya Zam Zam, Yogyakarta

Lembaga Alkitab Indonesia (LAI), 2013, Alkitab Deuterokanonika, diterbitkan dan dicetak oleh Lembaga Alkitab Indonesia, diterima dan diakui oleh Konferensi Wali Gereja Indonesia, Jakarta

Uer, Theodorus Uheng Koban, 20014, Landasan Kependidikan, Penerbit Nusa Indah Ende, Percetakan Moya Zam Zam, Yogyakarta

\section{Manuskrip}

Tim Penyusun Buku dan Modul, 2017, Konsep dan Pedoman Penguatan Pendidikan Karakter Tingkat Sekolah Dasar dan Menengah, Kementerian Pendidikan dan Kebudayaan, Republik Indonesia, Jakarta 


\section{Majalah-Majalah Inspiratif}

Relasi, Majalah Nasional Marriage Encounter Indonesia, diterbitkan oleh Dewan Nasional ME, Jakarta dan distribusikan secara periodik ke Dewan Distrik Dan Wilayah- Wilayah ME seluruh Nusantara.

Chatolic Life, Majalah Inspiratif dan Informatif, diterbitkan oleh Yayasan Pasintara, Jakarta, dan distribusikan ke seluruh wilayah Nusantara. 